\title{
СРАВНИТЕЛЬНО- ИСТОРИЧЕСКОЕ ЛИТЕРАТУРОВЕДЕНИЕ
}

\author{
Л.А. Гоготишвили
}

\author{
ВКЛАД ПОСТСИМВОЛИСТОВ ЛОСЕВА \\ И БАХТИНА В ТЕОРИЮ ПОСТРОЕНИЯ ДИСКУРСА \\ (ПРИНЦИПИАЛЬНЫЕ РАЗЛИЧИЯ НА ФОНЕ \\ ФУНДАМЕНТАЛЬНОГО СХОДСТВА)
}

Аннотация. В данной статье ведется сопоставление двух обычно резко противопоставляемых философов А. Лосева и М. Бахтина (это вторая из серии задуманных статей о соотночении позиций Лосева и Бахтина, первая статья - "Лингвистические пролегомены к теме "Лосев и Бахтин"»). Сопоставление ведется не столько по тематической, т.е. непосредственно содержательной стороне их философских построений (о кардинальных различиях между которыми, в частности, в оченке Возрождения, уже много написано), сколько с точки зрения схожести операционального уровня "интеллектуальной техники» обоих философов. Вместе с тем замысел состоял в проверке гипотезы, что сквозь сопоставление аналогичных операциональных уровней возможно разглядеть - при всей очевидности внешне тематических разногласий - схожие моменты глубинных тематических первоинтуиций. Сопоставление велось на четко определенном тематическом поле: оба философа работали в срере постсимволизма: как русского (с приоритетными аллюзиями к Вяч. Иванову), так и немецкого (т.е. в контексте немецкой классической философии - Гёте, Шеллинг, Гегель и др.,), а тем самым и в диалоге с неокантианством и феноменологией, которые в этом смысле можно толковать как постсимволистский этап немецкой философии. Показано, что именно тем, что развитие идей обоих философов шло по общим "постсимволистским" лекалам, определяется - при всем тематическом и аксиологическом различии - и их интеллектуально-техническая (операциональная), и интуитивно-тематическая, и в конечном итоге типологическая общность.

Метод исследования феноменологическое описание и сопоставление сравниваемых концепций как на историческом фоне (постсимволизм), так и на фоне современных когнитивных и нарративных теорий; применение двойной методологической оптики: одновременный поиск контрастных и типологически общих параметров. В результате исследования выявлено: 1) что под резко отличающейся тематической поверхностью текстов Лосева и Бахтина лежит схожая интеллектуально-операциональная техника, определяемая в своем сходстве общей установкой на постсимволизм, 2) что указанная операциональная общность лежит в основе тех смысловых тематических инноваций Лосева и Бахтина, которые по своему прямому тематическому составу, на первый взгляд, не имеют ничего общего (имяславие и двуголосие).

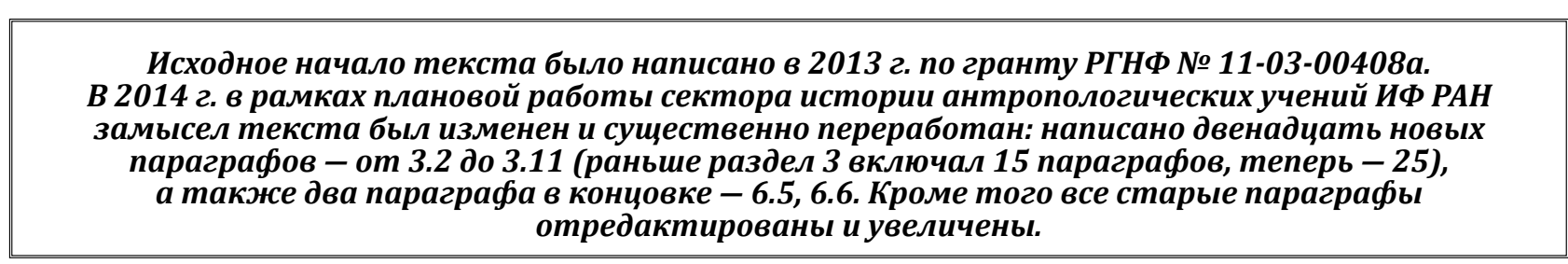




\section{Сравнительно-историческое литературоведение}

Обосновано, что и Лосев, и Бахтин работали с одними и теми же двумя феноменами, которые условно предложено называть двоччными и троичными символами, и что при этом операциональное обращение с этими феноменами оказывается у них по многим пунктам схожим.

Оспорена дискуссионная точка зрения, согласно которой двоичность выражает самую сердчевину русского типа философствования, в отличие от троичности, которая, как утверждается оппонентами, ею не приемлется - по тем или иным причинам, вплоть до «мистического испуга» перед постулируемым ею «третьим» элементом. В противовес распространенному мнению, что троичность не была адекватно воспринята русским символизмом в статье показано, что троичный символ не только признавался Лосевым и Бахтиным, но коррелировал с их ранними инновационными идеями. У раннего Лосева на концептуальном месте троичного символа говорится об имени (в контексте имяславия), у Бахтина - о двуголосом слове (ДС), ведущем в перспективе к полифонии.

Показано, что в лосевском имени как троичном символе непосредственно не данным третьим компонентом является сама сущность (она проявляется исключительно только через свою энергию); в бахтинском же ДС в качестве третьего (подразумеваемого) компонента можно понять скрытый - внешне никак лингвистически не маркированный - смысл отношения одного голоса к другому. Анализ всех дополнительных напластований в ДС составляет особую нарратологическую проблему, адекватно подойти к которой можно только через подробное рассмотрение феноменов символической двоччности и троичности.

В движении обоих философов в постсимволистском направлении в статье выделено две фазы: 1) релятивная, на которой оба двигались от троичного символа по направлению к тезису о релятивности языка, и 2) фаза адеквации, на которой оба философа равно обосновывали, что существуют такие стратегии порождения речи, которые преодолевают языковой релятивизм силами самого языкового релятивизма.

На фоне темы релятивности и ее преодоления обнажилось одно из значимых - и более того: типологических для русской философии начала ХХ века - сходств Лосева с Бахтиным: в статье высказана гипотеза, что с лосевской теорией относительных мифологий коррелирует бахтинская теория расхищенности единого языка на разные (профессиональные, жанровые, направленческие и т.д.) подъязыки, а с лосевской теорией абсолютной мифологии частично коррелирует полифоническая концепция Бахтина. Имеется в виду, что аналогично тому, как в лосевской абсолютной мифологии гасятся особенности относительных мифологий, так в бахтинской полифонии специфические подъязыки (голоса) входят в много векторные взаимные соотношения, которые гасят их специфическую релятивность и выводят высказывание в целом на адеквации. Такова только общая канва взаимоотношений абсолютной лосевской мифологии и бахтинской полифонии, за которой вскрывается взаимосвязанная система операциональных и тематических различий, в центре которой - противостояние диалектики и диалога.

Ключевые слова: Лосев, Бахтин, операциональность, тематизм, троичный символ, имя, двуголосие, Абсолютная мифология, полифония, дискурсивное преодоление языкового релятивизма.

1. Параметры сопоставления. Нас будет интересовать не столько непосредственно содержательная конкретика лосевских и бахтинских философских построений (об очевидных различиях между которыми, в частности, в оценке Возрождения, уже много написано), сколько операциональный уровень «интеллектуальной техники», за которой, однако, можно разглядеть и поддающиеся сопоставлению глубинные стержневые моменты тематических первоинтуиций. Такой подход представляется тем более правомерным, что он был не чужд как Лосеву, так и Бахтину: оба мыслителя придавали первостепенное значение наличию первоинтуиций в любой авторской философской системе и разделяли идею «спаянности» в ней операциональности с тематизмом.
Вот позиция Бахтина: «Постулятивность реальности, спаявшаяся с образностью и откровением, лежит в основе всех философем. Отсюда возможен ряд интересных работ: перевести обратно в образ -- откровение - нравственность то, что у великого философа изложено в теоретической форме (например, у Фихте). Типичным признаком выхода из чистого познания является смешение априорного и апостериорного (что от Фихте перешло в весь германский идеализм)».

Позиция Лосева: «...если брать реальную науку, т.е. науку, реально творимую живыми людьми

1 Лекции и выступления М.М. Бахтина 1924-1925 гг. в записях Л.В. Пумпянского. (http://az.lib.ru/p/pumpjanskij_1_w/ text_1925_lektzii_bahtina.shtml). 


\section{Филология: научные исследования 4(16) • 2014}

в определенную историческую эпоху, то такая наука решительно всегда не только сопровождается мифологией, но и реально питается ею, почерпая из нее свои исходные интуиции..», «..немало можно было бы установить аналогий и уравнений, если бы взяться за сопоставление всех «лунных» интуиций в различных религиях, искусствах и поэзии. Можно написать целую историю интуитивной мифологии луны; и этой увлекательной задачей займутся тотчас же, как только начнут серьезно относиться к непосредственным восприятиям жизни и перестанут заслонять от себя жизнь просветительским верхоглядством и абстрактной метафизикой, материалистической или спиритуалистической....» и др.2.

Я исхожу из предположения, что предлагаемый подход к сопоставлению концепций - от операционального уровня к тематическому - способен и на большее: он может помочь выявлению дополнительных параметров той одновременно и характерно-специфической, и типологически значимой для русской философии первой половины XX века ниши, контуры которой были намечены мною раньше ${ }^{3}$ : одна из специфических особенностей этой типологической позиции - преодоление языкового релятивизма силами самого релятивизма. Этот мотив по-особому сказался, как увидим, и у Лосева, и у Бахтина (к числу обитателей этой типологической ниши могут быть также отнесены такие мыслители, как Вяч. Иванов, П. Флоренский, С. Булгаков, Г. Шпет и др.).

\section{2. Постсимволистский контекст сопоставления}

2.1. Проводимая здесь содержательная редукция внешнего тематического состава обеих концепций в пользу операциональности (разумеется, неабсолютная) осуществляется здесь (в целях большей корректности сопоставления) на тематически едином и исторически четко определенном поле - символическом. Оба философа мыслили в едином концептуальном поле: в сфере постсимволизма - как русского (с приоритетными аллюзиями к Вяч. Иванову), так и немецкого, т.е. в контексте немецкой классической философии, где понятие символа в

\footnotetext{
2 Лосев А.Ф. Диалектика мифа. (http://philosophy.ru/library/ losef/dial_myth.html).

3 Гоготишвили Л.А. Шпет и Гумбольдт: феноменологические вариации на тему языкового универсализма и релятивности // Vox / Голос. Выпуск 12 (июнь 2012). (http://vox-journal.org/ content/Vox12-Gogotishvili.pdf).
}

его разных трактовках занимало значимое место (Кант, Гёте, Шеллинг, Гегель и др.,), а тем самым и в диалоге с неокантианством и феноменологией, которые в этом смысле можно отнести к постсимволистскому этапу в немецкой философии. Согласно предлагаемой гипотезе, развитие идей в фарватере постсимволистской парадигмы предопределяет при всех тематических и аксиологических различиях - операциональную и типологическую общность всех работавших на этом поде (с тематизмом дело обстоит сложнее). Под порой предельно поляризованной тематической поверхностью текстов Лосева и Бахтина, которых принято представлять едва ли не антиподами, просматривается - прежде всего на операциональном уровне - глубинное сходство, обусловленное общим символистским генезисом присущей им техники интеллектуального конструирования. Если состав тезаурусов данных философов номинально будет, скорее всего, существенно различаться, то свойственный обоим мыслителям mun структурно-семантического смыслового конструирования, составляющий основу «тезаурусного полотна», обнаруживает черты поразительного сходства, причем на самом глубинном уровне.

2.2. Вместе с тем следует отметить, что как раз в поле символизма фиксируется и одно из самых значимых - одновременно операциональных и тематических - различий между ними: если Лосев на всех этапах развития прямо эксплицировал свою связь с символизмом (от Платона до Вяч. Иванова), то в теоретизированиях Бахтина действовал своего рода запрет (разумеется, не абсолютный) на использование соответствующей терминологии, включая само понятие символа. Я предлагаю понимать это «терминологическое испарение» как специфическую «категориальную маскировку»: на деле в текстах Бахтина присутствуют практически все символистские темы, но они развертываются в иных категориальных декорациях, будучи «переодеты» в инотерминологические (несимволистские) одежды. Такая же склонность к прикровенности проявилась, как увидим, и у Лосева, но в другом аспекте. (Причин переодевания символической терминологии можно предположить много, но мы отвлечемся здесь от этой стороны дела). Косвенным, но весомым аргументом в пользу присутствия у Бахтина «несимволически терминированного символического» является максимально высокая оценка идей Вяч. Иванова как самим Бахтиным, так и всем «бахтинским кругом». В частности, в конце 10-х годов представители этого круга видели в Вяч. Иванове возможного те- 


\section{Сравнительно-историческое литературоведение}

оретического «вождя» (так, Л.В. Пумпянский в невельском докладе 1919 года «Достоевский как трагический поэт» писал: «И В. Иванов не встающее ли солнце?... ${ }^{4}$ ). Очевидна и преемственность Бахтина относительно ивановской разработки темы Достоевского, хотя здесь же локализовано, как известно, и самое принципиальное расхождение с Ивановым (в толковании романной полифонии Бахтин акцентировал внимание не столько на содержательных, сколько на конститутивно-формальных характеристиках этого феномена).

\section{3. Двоичная и троичная символизация у Лосева и Бахтина}

3.1. Оба мыслителя, прямо или косвенно разрабатывая в своих ранних трудах символистскую проблематику, учитывали оба конкурировавших в то время подхода к структуре символа, которые можно было бы назвать «двоичным» и «троичным». Первый основан на идее двоичности символа (в духе неоплатоников, Шеллинга и др.), второй - на идее его троичности (в духе Канта, Гегеля, Вяч. Иванова и др. $)^{5}$. Символ, постулировавшийся Шеллингом, предлагается называть двоичным в том смысле, что здесь наличествуют два (и только два!) участника «символического процесса»: внешний и внутренний слои выражения, которые оба понимаются как непосредственно данные (в том числе на уровне семантики или ноэматики) и способные сближаться вплоть до взаимоотождествления. Кроме двух слоев (в той или иной мере отождествленных) здесь нет ничего другого - ни третьего (или энного) слоя, ни смысловой предметности, на которую символ указывал бы поверх своего внутреннего слоя и смысла (таков, по Шеллингу и Лосеву, «организм»).

В троичном же символе, напротив, кроме непосредственно семантизованной в слове предмет-

\footnotetext{
4 Цит. по преамбуле Н.И. Николаева к работе Л.В. Пумпянского «О поэзии В. Иванова: мотив гарантий». (http://www.vivanov.it/wp-content/uploads/2011/03/pumpyansky_o_poezii_ ivanova_1925_2000_text.pdf).

5 Первичное и подробное разведение двоичного и троичного символа на фоне значения этого разведения в философии Лосева см.: Гоготишвили Л.А. Символ у раннего и позднего Лосева: сдвиг в толковании (реконструкция и опыт интерпретации) // Творчество А.Ф. Лосева в контексте отечественной и европейской культурной традиции. К 120-летию со дня рождения и 25-летию со дня смерти Материалы Международной научной конференции XIV «Лосевские чтения». Ч. I. M., 2013. C. 81-93.
}

ности (поверх нее), могут присутствовать разного рода дополнительные предметности (так, ивановский троичный и даже политроичный символ напр., змея «имеет ознаменовательное отношение одновременно к земле и воплощению, полу и смерти, зрению и познанию, соблазну и освящению» ${ }^{6}$ ). Эта дополнительная - семантически прямо не данная и лингвистически не маркированная - смысловая предметность и составляет, условно говоря, «третий» предметно-смысловой слой в символе. Иванов понимал символ троично вслед за Гёте, который в свою очередь следовал (прямо или через Шиллера) за Кантом: «...разве не на «преодоление» Канта, писал Вяч. Иванов, - надеется новая энергия метафизического творчества, которому законодатель всякого возможного познания поставил слишком стеснительные грани? - но преодолеть Канта не может. Обращаясь за дальнейшими примерами к области искусств, я сказал бы... <что> в сфере поэзии принцип символизма, некогда утверждаемый Гёте, после долгих уклонов и блужданий (видимо, связанных с Шеллингом и «двоичностью» - Л.Г.) снова понимается нами в значении, которое придавал ему Гёте (т.е. в троичном значении - Л.Г.), и его поэтика оказывается, в общем, нашею поэтикою последних лет».7

3.2. Оба толкования символа (двоичное и троичное), сыграли свою роль в формировании соответствующих концепций как у Лосева, так и у Бахтина, но прежде чем перейти к их анализу, коснусь дискуссионной точки зрения, согласно которой двоичность выражсет самую сердцевину русского типа философствования, в отличие от троичности, которая, как иногда утверждается, ею не приемлется - по тем или иным причинам, вплоть до «мистического испуга» перед постулируемым ею «третьим» элементом. Соответственно, двоичное понимание часто толкуется как «архаичное», а троичное - как «современное». Напр., в книге Михаила Ямпольского «Сквозь тусклое стекло» ${ }^{8}$ в сносках 49-53 и на соответствующих страницах самой книги (с. 68-70) автор помимо прочего развивает теорию, согласно которой в русском понимании символа господствует бинарность, в то время как подлинной сферой

\footnotetext{
6 Вяч. Иванов. Две стихии в современном символизме // Собр. соч. Т. 2. Брюссель, 1974. С. 536.

7 Вяч. Иванов. Гёте на рубеже двух столетий // Там же. Т. 4. C. 111 .

8 Ямпольский М. Сквозь тусклое стекло. М.: Новое литературное обозрение, 2010. С. 68-70.
} 


\section{Филология: научные исследования 4(16) • 2014}

зарождения и бытия символического является троичность Двоичная позиция, по Ямпольскому, выражает страх перед другим-третьим: «страх перед неопределенностью чего-то третьего, неописуемого, невидимого, не фиксируемого в видимых формах воображаемого...» (с. 69). В качестве витринного примера Ямпольский приводит мировосприятие В. Розанова, «переживавшего» предполагаемое снятие бинарности в третьем в сфере пола «как своего рода социально-историческую катастрофу. Розанов воображает, что «непременно появится третья психика - не мужская и не женская», а далее последуют еще более «страшные» вещи: «Таким образом глубочайше будет разрушен тип социальной жизни - разрушен не в бытовом, а в психологическом корне, т.е. более глубоко. То есть то разрушение, на месте которого ничего не вырастает. Не менее разрушается тип истории» (там же). В поддержку своего тезиса о принципиально двоичном понимании русской философией символа Ямпольский ссылается на Ю.М. Лотмана (с. 69, сноска 51), «выражавшего надежду на постепенное освоение Россией тернарности, или троичности». Доминированием бинарности он, в частности, объяснял непонимание Закона и законности в русской культуре: «B антитезе милости и справедливости русская, основанная на бинарности, идея противостоит латинским правилам, проникнутым духом закона...» ${ }^{9}$.

3.3. Вслед за постулированием страха русской философии перед «третьим» и сразу после ссылки на Лотмана Ямпольский переходит к Лосеву: «То же самое мы обнаруживаем и в философии Лосева, который понимал символ как воплощение идеи, а не как диалектический продукт различия» (там же, c. 69-70). Толкование очевидно неправомерное - и не только потому, что поздний Лосев акцентировал внимание именно на троичности, но и потому, что структура троичного символа (в модифицированном виде) была использована ранним Лосевым в толковании имени - центральной категории имяславия. Мимоходом замечу также, что представление о страхе перед троичностью у русских философов начала века, несомненно знакомых с религиозной тринитарной проблематикой, не только неверно по факту, но является нонсенсом по самой идее. У Лосева, в частности, есть в ОАСМ десятки страниц о троичности - т.е. о тринитарности, а значит, тро-

9 Лотман Ю.М. Культура и взрыв. М.: Гнозис, 1992. С. 260. (Цит. по: Ямпольский М. Сквозь тусклое стекло. М.: Новое литературное обозрение, 2010). ичность как таковая не могла не вызывать у него острой позитивной заинтересованности.

3.4. Проявлением этой же тенденции является известное упрощенное толкование имяславия, причем в его философских версиях, как по сути двоичного символизма, в котором Бог якобы отождествляется с его Именем. Отвлекаясь от других аспектов этой темы, скажу лишь, что пантеизм был глубоко чужд имяславию Лосева, в котором имя понималось как троичный символ, непосредственно проявляющий внешне только энергию сущности и оставляющий саму именуемую сущность неявленным третьим. Интересно, что некоторые научные теории, считающиеся основанными на двоичности со свойственной ей установкой на организм, часто расцениваются при этом западными исследователями как «неожиданно удачные»; так характеризуется, например, фонология Н.С. Трубецкого в книге Патрика Серио ${ }^{10}$ или имяславские мотивы в московской математической школе в книге Лорена Р. Грэхема и Жана-Мишеля «Имена бесконечности. Правдивая история о религиозном мистищизме и математическом творчестве» (Изд-во Европейского университета в Санкт-Петербурге, 2011 г.). В этой книге с некоторым недоумением признается возможность того, что имяславие стимулировало процесс создания дескриптивной теории множеств в рамках московской математической школы ММШ, с которой связаны имена Н.Н. Лузина и его последователей - П.С. Александров, А.Н. Колмогоров и др.; контакт с ММШ поддерживали и ученики Д.Ф. Егорова. (Интересно, что в русской рецензии на книгу возможность такого влияния отрицается ${ }^{11}$ ).

3.5. Каким образом можно обосновать это позитивное влияние? Грэхэм и Кантор утверждают, что, согласно Флоренскому и теории имяславия в целом, «именовать что-либо значит дать рождение новой сущности» (c. 97) и что причина позитивного влияния имяславия на математику в том и состояла, что имяславское учение породило у русских математиков веру в то, что «акт именования творит существование типов множеств», после чего и стала создаваться теория этих призванных к существова-

\footnotetext{
10 Серио Патрик. Структура и целостность: Об интеллектуальных истоках структурализма в центральной и восточной Европе. 1920-30-е гг. / Авторизованный перевод с франц. Н.С. Автономовой. М.: Языки славянской культуры, 2001.

11 Бажанов В.А. Имело ли место влияние имяславия на развитие математики? // Эпистемология \& Философия науки. 2010. T. XXVI. № 4.
} 


\section{Сравнительно-историческое литературоведение}

нию именованием множеств, в то время как осторожные французские математики, «придерживавшиеся традиций рациональности, не смогли этого сделать в силу ограничений, которые накладывались на их творчество рационализмом» (Бажанов, выше цит.), т.е. - интерпретирую - французские математики потому и отстали в теории множеств, что изначально не утвердили путем именования существование самих множеств. В упомянутой русской рецензии читаем: «...Если Лузин и верил в независимое существование математических объектов (в духе платонизма), то это никак непосредственно не отражалось на его математическом творчестве», которое продолжало оставаться всецело рациональным (в самом высоком смысле этого слова).

3.6. Отвлекаясь от сложной проблемы божественного творения словом, заметим очевидное: тезис о том, что дать имя - значит породить именованную сущность, звучит в духе двоичной интерпретации символа, точнее, в духе постулируемого в шеллингианской традиции символизма отождествления его двух слоев. Сама идея двоичности, согласно авторам книги, совпадающим в этом толковании с Лотманом и Ямпольским, ошибочна, но она, с их точки зрения, может оказаться продуктивной, поскольку расковывает интуицию и вызывает к жизни свободный творческий и интуитивный поиск.

3.7. Я не берусь судить о смысле теории множеств, но могу зафиксировать, что все эти рассуждения не имеют никакого отношения к реальному имяславию, поскольку имяславская имя 1) не двоично, а троично, поскольку оно 2) не дается человеком по своему произволу, а считается в имяславии идущим от самой сущности (само-именование) и поскольку 3) само имяславие есть не только мистическое умонастроение простецов, но и теория, разрабатывавшаяся некоторыми философами вполне рационально.

3.8. Что касается выставляемого авторами якобы имяславского тезиса, согласно которому «именовать что-либо значит дать рождение новой сущности» (с. 97), то ни один из теоретиков имяславия не взялся бы его защищать.

Приведу некоторые аргументы. Имя понималось всеми имяславцами не как сама сущность, а как ее энергия или как меональная ипостась энергии сущности. Следовательно, имя не могло пониматься как предшествующее сущности. Напомню, что Лосев, разработавший наиболее последовательную и рационально проработанную версию имяславия, толковал имя как само-имя сущности, по определению неспособной порождаться именем.

3.9. Вообще тезис о том, что акт именования творит существование типов множеств и что в этом и состоит суть влияния имяславия на математику, представляется мне применительно к русской философии крайне сомнительным; точной же ссылки на Флоренского, который якобы выдвигал этот тезис, Грэхем и Кантор в книге не дают. Этот тезис свидетельствует скорее о недостаточном, мягко говоря, внимании авторов к реальным имяславским текстам и об их опоре на общее - упрощенное и уплощенное - представление об имяславии, ограничивающееся только первой половиной имяславского тезиса («Имя Бога есть Сам Бог») и в упор не видящее второй его половины («...но Бог не есть имя»), вследствие чего адептам такого ущербного «толкования» остается только упражняться в псевдокритике несуществующего учения.

3.10. Вместе с тем вторая половина тезиса в развернутой редакции: «...но Бог не есть ни Его Имя, ни имя вообще» - дезавуирует основные возражения против имяславия. В наиболее продвинутых толкованиях имяславской формулы (во всей ее полноте) самими имяславцами отчетливо просматривается выше означенное развитие учения в сторону энергетизма.

3.11. Между тем «усеченное» понимание имяславия, ставшее, увы, едва ли не общепринятым даже в академических кругах (как отечественных, так и зарубежных), приводит при ближайшем (даже поверхностном) рассмотрении к полному абсурду. Если человеческое (не божественное!) именование порождает - на взгляд воображаемых имяславцев - сущность, то применительно к основному тезису имяславия придется сделать вывод, что именование порождает Бога. Абсурдность такого заключения достаточно очевидна даже для полного профана в имяславии. Но именно такое понимание лежит в основе теории Грэхэма и Кантора, согласно которой успехи русских ученых объясняются их верой в то, что давая имена неким математическим «сущностям», они сами начинали верить в их существование. Таким образом, приписывая русским мыслителям и ученым (в данном случае философски ориентированным математикам) «взгляд, конечно, очень варварский, но верный» (Иосиф Бродский), Грэхэм и Кантор становятся выразителями взглядов столь же варварских, сколь и неверных.

3.12. Не только «главный» русский символист Вяч. Иванов (что уже отмечалось), но и имяславец 


\section{Филология: научные исследования 4(16) 2014}

Лосев, и полифонист Бахтин активно использовали в своем конструировании идею троичности. Во всяком случае, и в построениях Лосева, и в концепциях Бахтина актуализированы два конститутивных свойства троичного символа: 1) то, что третий компонент никогда не дан в нем эксплицитно, он всегда подразумевается (в той или иной феноменологической форме), и (оборотная сторона) то, что в троичном символе 2) интенция расщеплена надвое: она направлена одновременно на предметность, непосредственно семантически данную (непосредственный внутренний слой), и на подразумеваемую предметность. Раздвоенность интенции троичного символа означает, что он имеет не одну, а две «позиции, на которые» направлена интенция акта. У интенционального акта здесь не одно феноменологическое «что», а два (в двоичном символе интенция, напротив, не расщеплена, а максимально уплотнена и сплочена в целостное одно посредством утверждения принципиального тезиса о потенциальном тождестве внутреннего и внешнего слоев).

3.13. Названные конститутивные особенности троичного символа породили один из основных сюжетов развития постсимволизма, который развертывался вокруг вопроса о том, как толковать природу расщепления интенции в троичном символе и, соответственно, природу самого третьего - семантически непосредственно не данного, но подразумеваемого - компонента. Лосев и Бахтин предложили, как увидим, каждый свою теорию свойственного троичному символу расщепляющего интенцию подразумевания.

3.14. Но сначала отметим еще одно существенное сходство: троичный символ, т.е. то, что считалось и именовалось символом у Канта, Гегеля и Иванова, у обоих наших авторов символом не называлось - либо только на ранних этапах (Лосев), либо на протяжении всего творческого пути (Бахтин). Если у раннего Лосева троичный символ заменен понятием имени (подробно см. выше цит. статью «Символ у раннего и позднего Лосева»), то у раннего Бахтина троичный символ заменен понятием двуголосого слова (ДС). При этом третий компонент троичного символа, включая и лосевское имя, и бахтинское ДС, неизменно квалифицировался обоими мыслителями - согласно вышеозначенному постулату - как не данный эксплицитно, но как «лишь» подразумеваемый. В поздних работах Лосев стал применять понятие символа к тому, что соответствовало троичному символу в его общем тогдашнем понимании и персонально лосевскому раннему имени. Что же касается позднего Бахтина, то он фактически отказался от термина символ; тем не менее, обе интерпретации символа - двоичное, и троичное - значимо присутствовали в бахтинских построениях в инотерминированной форме.

3.15. Что касается двоччного символа (в смысле шеллинговой двоичности), то он также был использован и ранним Лосевым, и ранним Бахтиным. У раннего Лосева в ДМ и ВИ имеются общеизвестные - прямые и разветвленные - аллюзии к двоичному шеллингианскому пониманию. Хотя уже и ранний Бахтин гораздо меньше Лосева использовал символистскую терминологию, у него тем не менее тоже легко найти безошибочно опознаваемую шеллингианскую двоичность - причем в неожиданных местах. Приведу некоторые из них.

3.16. Так, в АГ говорится о «художественносимволических (! - Л.Г.) жизненных выражениях реакции на целое человека, когда мы, обнимая или осеняя тело, обнимаем или осеняем и душу, заключенную в нем и выраженную им». Тело и душа здесь символически едины и неотрывно слиты (отождествлены) по типу шеллингианского двоичного символа. Хотя имя Шеллинга в АГ названо всего один раз и то - по касательной, аллюзия здесь несомненно ощутима (она тем более вероятна, что Шеллинг, как известно из бесед Бахтина с В.Д. Дувакиным, был одним из философских учителей Бахтина. Вот одна их бахтинских реплик в той беседе (после того, как Бахтин забыл имя Шеллинга и ему напомнили): «Это же ведь почти мое собственное имя. Как я мог его забыть! Я очень любил этого философа и знал его очень хорошо, вдоль и поперек» ${ }^{12}$ ).

3.17. Кроме этой почти прямой тематической аллюзии, шеллингианский двоичный символ присутствует в АГ и в операциональной - специфически бахтинской - модификации. Можно даже говорить о наличии в АГ своеобразной вариации шеллинговой идеи о трех типах соотношения между двумя слоями - выражаемым и выражающим. Сам Шеллинг, как известно полагал, что равновесие (или тождество) между слоями дает символ, перевес первого над вторым дает схему; а перевес второго над первым - аллегорию. Если мы заменим шеллингианское выражающее бахтинским «героем», а выражаемое - «автором», то получим три описанных в АГ типических случая, аналогичных шеллингианским: 1) перевес автора над героем - аналог

12 Бахтин М.М. Беседы с В.Д. Дувакиным. Шестая беседа. 23 марта 1973 года. (http://raritetclassic.com/publ/14-1-0-42). 


\section{Сравнительно-историческое литературоведение}

схемы, 2) перевес героя над автором - аналог аллегории и 3) подразумеваемый в АГ идеально-гипотетический третий случай равновесия автора и героя.

3.18. Именно этот гипотетически-идеальный случай, имеющий в генезисе шеллингианский двоичный равновесный символ, разовьется у Бахтина в дальнейшем в полифонию, в которой, согласно ее бахтинскому определению, нет перевеса или доминирования, поскольку автор и герой мыслятся в полифонии как диалогически равноправные (равновесные) акторы. Можно, казалось бы, предположить, что полифоническая художественная форма Бахтина предстает в этом контексте как символичная в двоччно-шеллингианском духе.

3.19. Однако это не совсем так. Тут необходимо учитывать историю становления формы. Полифоническая идея предполагает многоступенчатое функциональное расширение идеи символической троичности до двоичности: ведь полифонические отношения между автором и героем становятся двоичными только путем дискурсивной комбинаторики разных ДС, каждое из которых троччно. Не только троичность может быть результатом двоичности, но при определенных операциональных условиях и двоичность становится результатом троичности. Это - ядро полифонического замысла. Но подробное обсуждение этой проблемы - отдельная тема.

3.20. В нашем контексте важнее ответить на другой вопрос: какова дальнейшая судьба двоичного символа у Лосева (если троичный символ развился у него в имя)? В порядке гипотезы, не оснащаемой здесь доказательствами и необходимыми пояснениями, но представляющейся вполне вероятной, я предполагаю, что, двигаясь параллельным курсом, в смысловом соответствии (разумеется, не полном) с движением мысли самого Шеллинга, Лосев развил двоччный символ в миф (а в концептуальном пределе - в абсолютную мифологию). Во всяком случае и у раннего, и у позднего Лосева обосновывается тезис, что миф надо понимать буквально: миф есть то, что в нем говорится, а то, что в нем говорится, и есть миф. Сходным образом Лосев определял и свой ранний двоичный символ.

3.21. Предложенная сравнительная интерпретация судьбы двоичного символа у Бахтина и Лосева открывает новые возможности для выстраивания дальнейших параллелей. Прежде всего следует отметить, что в таком контексте отчетливо проявляется кардинальный для нашего сопоставления вопрос: можно ли понимать двоично-равновесную бахтинскую полифонию как аналог также развившейся из двоичного символа лосевской мифологии? Понятно, что речь здесь идет только об абсолютной мифологии. Ответ: и да, и нет. Мы поясним этот двойственный ответ ниже (в параграфе 6.4), поскольку он требует предварительного обсуждения некоторых дополнительных тем (в частности, вопроса, имеются ли у Бахтина аналоги лосевских относительных мифологий).

3.22. Однако одно значимое сходство между абсолютной мифологией и полифонией можно отметить уже сейчас, вне зависимости от дальнейших сопоставлений: двоичный символ, составляющий корень и бахтинской полифонии, и лосевской абсолютной мифологии, равно представляют собой не изолированно-единичное, а развернуто-дискурсивное явление. Полифония и Абсолютная мифология трансформируются обоими философами из единичной и изолированной семемы или лексемы в развернутую нарративную структуру: и полифония, и абсолютная мифология возможны только как разветвленный дискурс (Напомню из Лосева: «Миф есть развернутое магическое имя», а у Вяч. Иванова миф определялся как синтетическое суждение с символом-подлежащим).. Таким образом, и Лосев, и Бахтин понимали символизм, как минимум, предикативно (значимость этого обстоятельства можно понять по той острой дискуссии, которая развернулась, как известно, вокруг предикативного понимания метафоры, которая также в некоторых версиях имеет отношение к символу), на деле же - дискурсивно, т.е. как свойство, «разлитое» по всему данному тексту («пронизывающее» все высказывание).

3.23. Последний момент предопределил финал обеих рассматриваемых концепций: в конечном итоге конститутивный принцип символизма (постулирующий возможность соприкосновения или корреляции внутреннего смысла с внешним выражающим слоем) был трансформирован обоими философами в особые дискурсивные стратегии, позволяющие тексту достичь искомого адекватного выражения внутреннего смысла - т.е. того, что по определению лежало в основе двоичного символа. Обратим внимание, что при этом изменилась форма достижения адекватности: она проделала путь от прямой (и относительно элементарной) двоичности до дискурсивно изощренной комбинаторики троичности.

3.24. Наконец, если условно закруглить тему о двоичной и троичной символике применительно к нашей узкой сопоставительной задаче, можно 


\section{Филология: научные исследования 4(16) 2014}

вывести следующее гипотетическое заключение. Маршрут развития и поддающиеся сопоставлению характеристики символических (по своему генезису) идей Лосева и Бахтина во многом были детерминированы ситуацией, сложившейся внутри символизма в начале XX века. Наличие в XIX-м - начале $\mathrm{XX}$-го веков двух противоборствующих толкований символа отражало две тенденции тогдашнего гуманитарного мышления. Тот факт, что троичный символ со временем одержал полную победу над двоичным, отражал ситуацию кризиса языка и означал нарастание релятивной тенденции (движущей силой которой служил «третий фактор», т.е. мыслимый как истинный, но остающийся прямо не выраженным, а лишь подразумеваемым предметный смысл такого символа). Двоичный же символ, напротив, постулировал идею возможности адекватного языкового выражения, которая сохраняла свою значимость даже на фоне признания релятивности языка как такового. И Лосев, и Бахтин, глубоко усвоившие обе версии толкования символа, каждый по-своему сплели, сочленили обе тенденции: в своем творческом развитии и Лосев, и Бахтин прошли через фазу утверждения языкового релятивизма и нашли выход из кризиса в конструировании таких - новых относительно идеи двоичности - дucкурсивных стратегий, которые этот релятивизм способны преодолеть. (У Лосева двоичная Мифология вырастает из троичного имени, у Лосева двоичная адекватная полифония - из троичного ДС).

3.25. Поскольку эти две тенденции - релятивности и адеквации - были для них общим «генетическим бэкграундом», Лосев и Бахтин схожи - по принципам их сочленения и наличию двух фаз - не только между собой. Данный двухфазовый сюжет можно признать общим для той типологической ниши в русской философии начала XX века, о которой говорилось выше (от европейских концепций со схожими сюжетами я здесь отвлекаюсь). В основе этой типологической общности - тезис о продуктивности скрещения двух названных идей за счет особых дискурсивных стратегий. Тезис о возможности достижения адеквации при помощи специальных дискурсивных стратегий основан на идее преодоления языковой релятивности силами самой релятивности. Бахтинская полифония - как одна из таких стратегий - в этом плане особенно наглядна: основанная на отсутствии доминирования голоса автора и сотканная из сплошь релятивных (субъективных) голосов героев, она тем не менее предполагает адекватное выражение со- ответствующего «события бытия» в полифонической дискурсивной форме. Лосев выдвинул свою дискурсивную стратегию достижения адеквации, основанную на идее позиционной политропии (см. раздел 6). Кроме полифонии и позиционной политропии, к описываемой типологической нише можно отнести дискурсивную стратегию кругового и кустового антиномизма Вяч. Иванова, «круглое изложение» Флоренского, круговой полиформизм Шпета и др. Сами дискурсивные стратегии, предлагаемые разными авторами, разумеется, различны, и в этих различиях коренится основной философско-сопоставительный интерес, однако у них имеется и ряд типологически общих или аналогичных установок. Воспроизведу основные общие характеристики этой типологической ниши, предложенные мной ранее в приведенной выше статье «Шпет и Гумбольдт: феноменологические вариации на тему языкового универсализма и релятивности» ${ }^{13}$ : «1) акцент на операциональном (энергийном) подходе к языку, 2) признание специфичности и значит, условности, а в пределе - релятивности, каждого конкретного языка и подъязыка (жанров, направлений, субъективных языков и т.д.); 3) антиномичное на этом фоне утверждение возможности универсальной стратегии речепорождения, способной привести к адекватному высказыванию на любом языке; 4) идея немаркированности этой универсальной стратегии регулярными лингвистическими индексами; 5) толкование стратегий как опосредованно непрямых и не рационально-логических и, наконец, - это базовая стратегема описываемой типологической тиши - 6) идея преодоления релятивности конкретных языков силами самой релятивности ... По замыслу и содержательно я предлагала определять данный подход как «теорию взаимозависимости и взаимообратимости в процессе речепорождения релятивных и универсальных сторон языка».

\section{4. Сходства и различия фазы языкового релятивизма у Бахтина и Лосева}

4.1. Релятивные ноты по отношению к языку звучали у Бахтина с самого начала, но эти «умонастроения» приобрели очертания строгой когерентной теории только в работе 30-х гг. «Слово в романе» (СВР), т.е. уже после АГ и изданных в 1929 г. «Про-

\footnotetext{
13 Vox / Голос. Выпуск 12 (июнь 2012). (http://vox-journal.org/ content/Vox12-Gogotishvili.pdf).
} 


\section{Сравнительно-историческое литературоведение}

блем творчества Достоевского» (ПТД). В СВР ситуация с символической двоичностью - по сравнению с тем, какой она предстает в АГ, - инверсивно осложнена за счет новой, специфически бахтинской аранжировки темы. Обосновывая тезис об интенциональной расхищенности общего (единого) языка, Бахтин в СВР одновременно и углубляется в стихию языка, и выходит непосредственно к его внешним пределам, релятивируя и эти границы, и внутреннюю территорию языка в целом. Язык, согласно бахтинскому СВР, расхищен на разного рода и типа (условно) «подъязыки» - мировоззренческие, профессиональные, научные, религиозные, направленческие, поколенческие, жанровые, стилистические и т.д. Я предлагаю рассматривать каждый из этих бахтинских подъязыков как - в символическом смысле - двоичный, поскольку он прямо (т.е. посредством свойственного двоичному символу тождества выражающего и выражаемого) передает характерный именно для этого типа подъязыка смысл. Эта дискурсивная сфера допускает гораздо более адекватное применение шеллингианской двоичности, чем та, с которой имеет дело полифония. Выражающий и выражаемый слои в бахтинских подъязыках слиты, отождествлены или - сращены («Расслояется и дифференцируется не нейтрально-лингвистический состав языка, а расхищаются его интенциональные возможности»: осуществляясь «в определенных направлениях, они наполняются, конкретизуются, специфицируются» и потому «пропитываются конкретными оценками, срастаются с определенными предметно-смысловыми и экспрессивными - жанровыми и профессиональными кругозорами») ${ }^{14}$. Такова же, по Бахтину, и сфера поэтического языка - это именно подъязык с двоичным символическим потенциалом. Что же касается прозаического языка, всегда основанного на двуголосом слове (как получается при таком толковании), то он, напротив, принципиально не двоичен, а, как минимум, троичен (или еще более многосоставен - см. ниже раздел 5 и, в частности, сноску 17).

4.2. Однако бахтинские жанровые и профессиональные «подъязыки» являются такими двоичнотождественными, т.е. «прямо-интенциональными» (непосредственно и точно свидетельствующими по законам двоичной символики - о своем смысле) лишь для самого говорящего на этих подъязыках

14 Бахтин M.M. Слово в романе. (http://www.gumer.info/ bibliotek_Buks/Literat/bahtin/slov_rom.php). (т.е. «изнутри» соответствующих «кругозоров»). Только и исключительно изнутри каждого подъязыка, включая поэзию, всякий символ локализуется в едином, интенционально и диалогически не расслоенном и не расхищенном пространстве, поэтому он и имеет возможность функционировать в этом поле так, чтобы выражающий слой (внешний слой языковых значений) непосредственно примыкал к выражаемому (внутреннему смысловому слою). Внутри каждого данного подъязыка конкуренция внешних языковых форм за право выражения по поводу данного характерного смысла для всех других, не входящих в данный подъязык форм, бесперспективна (бессмысленна).

4.3. С понятием расхищенности языка на подъязыки мы вышли на искомые бахтинские аналоги относительных мифологий Лосева. Действительно, сознание, находящееся внутри любой такой мифологии, так же, как и в случае бахтинского подъязыка, воспринимает ее - и только ее - как ту развернуто-дискурсивную двоичную символику (развернутый «магический символ»), которая одна способна достичь полной адеквации с сущностью. Сознание же, находящееся вне каждой данной относительной мифологии, не видит адеквации в ее прямой интенциональности.

4.4. Поскольку каждая относительная мифология непосредственно интенциональна для разделяющего ее сознания, она вся пронизана системной двоичной символикой. Это означает, что ее частно-характерные смыслы в той или иной степени срастаются (отождествляются - по принципу шеллингианской двоичности) с соответствующими внешними языковыми формами, вследствие чего лосевская теория относительных мифологий могла послужить таким же истоком релятивизации естественного языка, каким для Бахтина служила его теория интенциональной расхищенности единого языка на подъязыки.

4.5. Помимо учения об относительных мифологиях, идея языкового релятивизма была заложена у раннего Лосева также в теории апофатизма, а идея преодоления релятивизма, т.е. достижения адеквации - в теории синтеза апофатизма и символизма. Можно также отдельно говорить и о лосевской теории релятивности, как она сложилась в поздний период. В предельно сжатом виде ее можно передать следующим образом: что угодно может быть выражено как угодно (поскольку языковое выражение как таковое в глубине своей релятивно): ««Знак вещи манифестирует нам эту вещь, впервые 


\section{Филология: научные исследования 4(16) • 2014}

повелевает признать ее существование. А уж дальше наше сознание и наша мысль могут как угодно глубоко анализировать эту вещь и как угодно далеко отходить от ее непосредственного называния. Наше сознание и наша мысль в результате нашего исследования могут даже переименовать нашу вещь, дать ей другое название, употребить другой термин и вместо первичного и непосредственного называния вещи прийти к необходимости употребить здесь целое множество разных названий и терминов, то есть разных знаков» ${ }^{15}$.

4.6. Таким образом, сходство «релятивных фаз» развития Лосева и Бахтина представляется мне совершенно очевидным. Поскольку в обоих случаях мы имеем дело с использованием комбинаторного потенциала двоичной и троичной символики, указанное сходство носит преимущественно операциональный характер. Зафиксируем предварительные итоги: у обоих философов идея релятивизации поддерживается общим операциональным «ходом», согласно которому и чуждый для какого-либо «внешнего» сознания подъязык Бахтина, и чуждая какому-либо «внешнему» сознанию относительная мифология не просто воспринимаются этим сознанием как неверные (ложные), но и - как характерно-типичные. При этом типичность характеризует не только выраженный смысл, но и тип сознания, находящего выражение «своего» смысла на данном подъязыке или разделяющего данную относительную мифологию (взаимопронизанность типа сознания и типа языка и/ или мифологии - очередной общий отблеск идеи двоичной символики). Извне же подъязыков и/ или относительных мифологий их выражающая сторона воспринимается как условная - как так или иначе ограниченная (или, как говорил Бахтин, «пахнущая») своим контекстом: мировоззрением, мифологией, профессией, направлением и т.д. («... интенции, пронизывающие эти <подъ>языки, для непричастных оплотневают, становятся смысловыми и экспрессивными ограничениями, отягощают для них и отчуждают от них слово, затрудняют для них прямо-интенциональное, безоговорочное употребление его» ${ }^{16}$ ). При восприятии извне все подъязыки и относительные мифологии транс-

15 Проблема символа и реалистическое искусство. М., 1976. (http://www.gumer.info/bibliotek_Buks/Culture/Los_PrSimv/02. php).

16 Бахтин М.M. Слово в романе. (http://www.gumer.info/ bibliotek_Buks/Literat/bahtin/slov_rom.php). формируются из прямо и полно интенциональных (двоичных) в «объектные, характерные, колоритные», а в этой своей характерности - в условно-релятивные и троичные. Двоччность, таким образом, оказывается в обоих случаях истоком релятивизации языковых выражений. И источником третьей подразумеваемой предметности.

4.7. Идея релятивности, таким образом, генетически увязана у обоих авторов и с троччной символикой, поскольку именно в троичном символе выражающий слой содержит релятивный по своей природе слой: сознание начинает усматривать сквозь этот слой нечто иное (третье) - то, что прямо в этом выражающем слое не дано и по отношению к чему и этот третий слой, и два предыдущих - все оказываются релятивными.

4.8. Так, во внешнем слое троичного символа просматривается, по мнению позднего Лосева, иная, чем непосредственно данная, смысловая предметность. Лермонтовские строки «Мы пьем из чаши бытия с закрытыми глазами» (из «Чаши жизни») представляют собой, по Лосеву, троичный символ потому, что они несут в своей внешней выражающей плоти третий - семантически не явленный, но несомненно подразумеваемый - смысл, а именно: «безотчетное и слепое пользование жизнью, или стремление жить» (так Лосев определяет эту третью смысловую предметность в ДХФ; любопытно отметить, что эти же лермонтовские строки использованы как пример троичности не только в поздней «Проблеме символа», но и в ранней ДХФ).

4.9. Существенно также, что у обоих мыслителей в качестве третьего компонента могут выступать не только предметности в узком смысле слова, но и многие другие смысловые образования. Так, и у Бахтина за внешней формой подъязыка, и у Лосева за внешней формой относительной мифологии просматривается, в качестве третьего, характерный лик того человека (или - тип того сознания), который прямо и безоговорочно пользуется этим подъязыком или этой относительной мифологией. И бахтинский подъязык, и лосевская относительная мифология, функционирующие в органичной для себя сфере (изнутри сознания) как двоичные, в «чужом» (внешнем) контексте и для чужого сознания становятся, как мы видели, символами троичными. Тип символа, таким образом, понимался нашими авторами как условный - контекстуально зависимый. Обобщая, можно сказать, что троичность как таковая мыслилась обоими, по всей видимости, как неизбежный результат эволюционного изощрен- 


\section{Сравнительно-историческое литературоведение}

ного развития двоичных символов в эгологически усложнившейся обстановке (имеются в виду и разного рода расщепления Я, и вступления Я внутри высказывания в разного рода диалогические отношения с разными внешними Другими - Ты, Он, Оно, Мы, Все и т.д. (т.е. - со всем замкнутым местоименным циклом).

\section{5. Бахтинское двуголосое слово как троичный символ}

5.1. На описанном преображении двоичности в троичность основано конститутивное для всей бахтинской концепции понятие двуголосого слова (ДС), которое - как можно уже было понять по предшествующему - предлагается здесь понимать в качестве бахтинского аналога или функционального заместителя троичного символа. У раннего Лосева таким аналогом было, напомним, имя (Напомню главные моменты лосевского смещения вектора троичности с символа на раннее имя по работе «Символ у раннего и позднего Лосева: сдвиг в толковании (реконструкция и опыт интерпретации» (Выше цит.): троичным символом у раннего Лосева является имяславское имя, в котором как минимум три слоя - сущность, энергия сущности и языковая плоть (внешний выражающий слой). С формальной точки зрения, языковое внешнее выражение непосредственно знаменует в имени саму именуемую сущность, т.е. действует как бы по типу двоичного символа, но имяславец Лосев толкует ситуацию иначе. По Лосеву, имя знаменует не сущность, а только энергию сущности (поскольку все что мы познаем в сущности, мы познаем только в свете ее энергий). И только через эту энергию, ознаменованную в символическом имени, мы можем выйти на саму сущность, которая потому и квалифицируется как третий - не эксплицированный и подразумеваемый - компонент в этом троичном символе-имени. В лосевском имени, таким образом, две предметности: одна - явно-данная (одна из форм энергии), вторая - сама сущность, на которую указывает эта первая энергетическая по природе данность).

5.2. Специфика структуры ДС состоит, как известно, в том, что она, будучи формально единой (исходящей от одного говорящего) конструкцией, несущей с виду один прямой смысл, на деле скрещивает два голоса (значит, смыслов, как минимум, уже два). Существенно при этом, что об этом скрещении «знает» только один из голосов - он и доминирует над другим, т.е. над смыслом другого голоса, как-либо, явно или латентно, оценивая его, так или иначе, хотя бы чисто тонально, высказываясь о нем, обобщенно говоря - предицируя его (второй голос при этом никак в составе ДС на эту оценку не отвечает - не может ответить, так как не имеет такой формальной возможности). Смысл этой оценки и предицирования становится в высказывании еще одним дополнительным - третьим и подразумеваемым - смыслом, а само высказывание становится в символическом отношении троичным. Существенно, что этот дополнительный бахтинский смысл - как и положено третьему компоненту в троичном символе - непосредственно семантически в ДС не явлен, он подразумевается.

5.3. Мы видим, таким образом, что в ДС, как в гегелевском троичном символе, в его лосевской интерпретации, «предметы и изображения используются не как выражения своего «непосредственного смысла», а как выражения «иного смысла». Так, если лев - помимо своего непосредственного смысла «льва» несет, являясь троичным символом, другие смыслы - великодушия, силы и др., то ДС несет тот дополнительный смысл, который отражает отношение одного голоса к другому.

5.4. Пример ДС как аналога троччного символа (третьим компонентом становится отношение первого - ведущего - голоса ко второму). Пример взят у Бахтина (ППД). Когда в своей внутренней речи Раскольников сначала спрашивает, почему Дуня и мать допускают такую жертву со стороны Дуни в пользу Раскольникова (брак с Лужиным по расчету), затем сам же на этот вопрос и отвечает, мысленно (но неэксплицированно) опираясь на письмо матери:

«<..> Ясно, что тут не кто иной, как Родион Романович Раскольников в ходу и на первом плане стоит. Ну как же-с, счастье его может устроить, в университете содержать, компаньоном сделать в конторе, всю судьбу его обеспечить; пожалуй, богачом впоследствии будет, почетным, уважаемым, а может быть, даже славным человеком окончит жизнь! А мать? Да ведь тут Родя, бесценный Родя, первенец! Ну как для такого первенца хотя бы и такою дочерью не пожертвовать!».

Во фрагменте: «Да ведь тут Родя, бесценный Родя, первенец! Ну как ради такого сына хотя бы и такою дочерью не пожертвовать» - «третьим смыслом» является горькая ирония Раскольникова, т.е. его оценочная (тональная) предикация смысла позиции матери (в приведенном тексте эта 


\section{Филология: научные исследования 4(16) • 2014}

тональная предикация Раскольникова прямо семантически не выражена, хотя ниже она будет дана непосредственно; тем не менее читатель понимает иронию и до ее прямого выражения). По формальной структуре, таким образом, мы имеем прямую аналогию троичному символу. (На деле, конечно, заранее ясно, что ситуация в ДС многосоставней: в качестве третьего смысла можно понять уже смысл второго голоса, поскольку он также внутренне скрыт за внешне принадлежащей одному голосу и внешне «односмысловой» конструкции. Так, в любой ироничной фразе мы слышим не только смысл фразы в целом и не только того, кто иронизирует и является номинальным хозяином фразы, но и того, над кем иронизируют, т.е. слышим три смысла. Но поскольку иронизирующий «хозяйский» голос внутри также интенционально расщеплен по описанной выше операциональной схеме: он говорит и о предмете (референте) высказывания - это его первый интенциональный предмет и смысл, и о чужом высказывании о том же предмете (второй смысл первого голоса), то при таком подсчете смысл отношения одного голоса к другому становится уже «четвертым» смысловым слоем (1. смысл фразы в целом, 2. смысл второго голоса, два смысла первого голоса: 3. его отношение к предмету и 4. его отношение ко второму голосу). Но поскольку нас прицельно интересует здесь присутствующий в ДС принцип троичности, мы отвлечемся от этих дополнительных напластований, анализ которых составляет особую нарратологическую проблему (связанную с постановкой авторского голоса), адекватно подойти к которой можно только через подробное рассмотрение как самих двоичности и троичности, так и их разного рода взаимных напластований в разных типах дискурса).

5.5. Отметим, что в ДС срабатывает и вторая, сформулированная нами выше, универсальная закономерность: двоичный символ становится троичным в случае перенесения его в чужой контекст. Тот же смысл в устах (в контексте речи) матери звучит как органичное прямое выражение, нацеленное на отождествление внутреннего и внешнего слоев; иными словами, в устах матери он структурирован как двоччный символ. А в устах Раскольникова эти же слова воспринимаются как аналог троичного символа. Контекстуальная смена символом своего структурного типа лишний раз подтверждает универсальную общелингвистическую закономерность, согласно которой значение слова определяется контекстом.

\section{6. Бахтинская полифония на фоне лосевской абсолютной мифологии и позиционной политропии}

6.1. Мы вернулись к поставленному выше (3.11) вопросу. Конечно, аналогия между бахтинской полифонией и лосевской абсолютной мифологией не является ни прямой, ни, тем более, полной, но концептуальные поля этих интеллектуальных конструкций пересекаются. С одной стороны, полифония и абсолютная мифология схожи, поскольку каждая из этих теорий возникла на выходе из релятивного этапа творчества обоих мыслителей и выполняла задачу преодоления релятивности и возврата - на новом уровне - к чаемой адеквации; иными словами, в лице полифонии и абсолютной мифологии мы имеем дело с фазой «новой адеквации», гораздо более проработанной и изощренной, чем основанная на двоичном символе «старая адеквация» шеллингианского толка. С другой стороны, ядро этих концептов принципиально не совпадает. Не вдаваясь в подробности, отмечу в этом несовпадении лишь два момента.

6.2. Во-первых, необходимо подчеркнуть то решающее обстоятельство, что если в абсолютной мифологии Лосева адекватность достигается диалектическим путем, при помощи синтеза относительностей, то в полифонии Бахтина диалектика замещается диалогом, в котором синтез невозможен. Бахтинская полифония предполагает иной путь достижения адекватности: за счет попеременного проведения всех голосов в разных двуголосых конструкциях одного дискурса по всем возможным позициям (как доминирующим, так и подчиненным), в результате чего каждый голос подвергается диалогической предикации со стороны всех других голосов и сам диалогически продуцирует все другие голоса. Это, по замыслу, и придает голосам-участникам «полифонического процесса» равноправие, а тем самым достигается и искомая адекватность.

6.3. Второе принципиальное отличие состоит в том, что если полифония является дискурсивной стратегией, то лосевская абсолютная мифология есть не только стратегия построения адекватного дискурса, но в определенном смысле и непосредственно сам этот адекватный дискурс.

6.4. Поэтому более корректным аналогом полифонии как стратегии достижения адеквации представляется на первый взгляд не столько абсолютная мифология (нагруженная религиозно-идеологическими коннотациями), сколько заложенная 


\section{Сравнительно-историческое литературоведение}

в лосевских текстах дискурсивная стратегия достижения адеквации. Речь идет о стратегии позиционной политропии, согласно которой адекватность достигается за счет проведения каждого релятивного выражения данной предметности по всем возможным и внутренне соотносимым тропологическим позициям (метафора, олицетворение, символ, аллегория и т.д. $)^{17}$.

Однако обсуждавшийся здесь новый ракурс рассмотрения темы позволяет предложить иную интерпретацию, сглаживающую возникший диссонанс.

6.5. В порядке гипотезы, требующей дальнейшего обоснования, выскажу предположение, что Абсолютная Мифология все же, несомненно, задумывалась Лосевым как содержащая в себе алгоритм построения адекватного высказывания. Лосев был убежден в том, что адекватные тексты выстраиваются по диалектическим лекалам снятия напряженности, а в Абсолютной Мифологии именно этот алгоритм прописан максимально развернуто и подробно (напомню, что Абсолютная Мифология тождественна у Лосева Абсолютной Диалектике).
6.6. Позиционная же политропия в этом свете представляет собой редуцированный слепок с Абсолютной Мифологии. Различие в том, что если в Абсолютной Мифологии двигателем диалектики является тематизм, то в политропии эту функцию выполняет операциональность. Предлагаемая идея операциональной диалектики основывается на том, что тропы, в круге которых вращается в этой стратегии предметный смысл, состоят между собой в диалектических отношениях, но не тематических, а операциональных. Не случайно Лосев активно и постоянно стремился выстроить некую лестницу, или иерархию, тропов, причем так, чтобы эта диалектическая иерархия строилась по нарастанию (синтезу) или убыванию (снятию) какого-либо признака, например, плоскостной живописности (см. 3СМ). Это, вне всякого сомнения, диалектическая по духу стратегия построения типологии тропов. Если так, то Абсолютную Мифологию следует понимать как тематическую, а позиционную политропию - как операциональную дискурсивную стратегию, при том, что обе они - как то и должно быть у Лосева - являются диалектическими.

\section{Список литературы:}

1. Бажанов В.А. Имело ли место влияние имяславия на развитие математики? // Эпистемология \& Философия науки. 2010. Т. XXVI. № 4.

2. Бахтин М.М. Беседы с В.Д. Дувакиным. Шестая беседа. 23 марта 1973 года. (http://raritetclassic.com/publ/14-1-0-42).

3. Бахтин М.М. Лекции и выступления М.M. Бахтина 1924-1925 гг. в записях Л.В. Пумпянского. (http://az.lib.ru/p/ pumpjanskij_l_w/text_1925_lektzii_bahtina.shtml).

4. Бахтин М.М. Слово в романе (СВР) (http://www.gumer.info/bibliotek_Buks/Literat/bahtin/slov_rom.php).

5. Бродский Иосиф. Вот и прожили мы больше половины. Цикл «Письма римскому другу (из Марциала)». (http:// www.booksite.ru/localtxt/bro/dsk/ii/brodskii_i_a/sochineniya/28.htm).

6. Гоготишвили Л.А. «Позиционная политропия» как стержневой принцип лосевской теории высказывания // Философия и культура. 2010. № 3. С. 81-89.

7. Гоготишвили Л.А. Шпет и Гумбольдт: феноменологические вариации на тему языкового универсализма и релятивности // Vox/Голос. Выпуск 12 (июнь 2012). (http://vox-journal.org/content/Vox12-Gogotishvili.pdf).

8. Грэхем Лорен Р., Кантор Жан-Мишель. Имена бесконечности. Правдивая история о религиозном мистицизме и математическом творчестве. СПб.: Изд-во Европейского университета в Санкт-Петербурге, 2011.

9. Иванов Вяч. Гёте на рубеже двух столетий // Иванов Вяч. Собр. соч. Т. 4. Брюссель, 1974.

10. Иванов Вяч. Две стихии в современном символизме // Иванов Вяч. Собр. соч. Т. 2. Брюссель, 1974.

11. Лермонтов М.Ю. Чаша жизни. 1831. Подражание Байрону. (http://feb-web.ru/feb/lermont/texts/lerm06/vol01/le1206-.htm).

12. Лосев А.Ф. Абсолютная Диалектика - Абсолютная Мифология. (http://philosophy.ru/library/losef/abs.html).

13. Лосев А.Ф. Диалектика мифа. (http://philosophy.ru/library/losef/dial_myth.html).

14. Лосев А.Ф. Проблема символа и реалистическое искусство. М. 1976. (http://www.gumer.info/bibliotek_Buks/Culture/ Los_PrSimv/02.php).

15. Лосев А.Ф. Философия имени. (http://www.gumer.info/bogoslov_Buks/Philos/fil_im/).

16. Лотман Ю.М. Культура и взрыв. М.: Гнозис, 1992.

17 Подробное изложение дискурсивной стратегии позиционной политропии было дано ранее см.: Гоготишвили Л.А. «Позиционная политропия» как стержневой принцип лосевской теории высказывания // Философия и культура. 2010. № 3. C. 81-89. 


\section{Филология: научные исследования 4(16) • 2014}

17. Николаев Н.И. Предисловие // Пумпянский Л.В.О поэзии В. Иванова: мотив гарантий. (http://www.v-ivanov.it/wpcontent/uploads/2011/03/pumpyansky_o_poezii_ivanova_1925_2000_text.pdf).

18. Серио Патрик. Структура и целостность: Об интеллектуальных истоках структурализма в центральной и восточной Европе. 1920-30-е гг. / Авторизованный перевод с франц. Н.С. Автономовой. М.: Языки славянской культуры, 2001.

19. Ямпольский М. Сквозь тусклое стекло. М.: Новое литературное обозрение, 2010.

\section{References (transliteration):}

1. Bazhanov V.A. Imelo li mesto vliyanie imyaslaviya na razvitie matematiki? // Epistemologiya \& Filosofiya nauki. 2010. T. XXVI. № 4.

2. Bakhtin M.M. Besedy s V.D. Duvakinym. Shestaya beseda. 23 marta 1973 goda. (http://raritetclassic.com/publ/14-1-0-42).

3. Bakhtin M.M. Lektsii i vystupleniya M.M. Bakhtina 1924-1925 gg. v zapisyakh L.V. Pumpyanskogo. (http://az.lib.ru/p/ pumpjanskij_l_w/text_1925_lektzii_bahtina.shtml).

4. Bakhtin M.M. Slovo v romane (SVR) (http://www.gumer.info/bibliotek_Buks/Literat/bahtin/slov_rom.php).

5. Brodskii Iosif. Vot i prozhili my bol'she poloviny. Tsikl «Pis'ma rimskomu drugu (iz Martsiala)». (http://www.booksite.ru/ localtxt/bro/dsk/ii/brodskii_i_a/sochineniya/28.htm).

6. Gogotishvili L.A. «Pozitsionnaya politropiya» kak sterzhnevoi printsip losevskoi teorii vyskazyvaniya // Filosofiya i kul'tura. 2010. № 3. S. 81-89.

7. Gogotishvili L.A. Shpet i Gumbol'dt: fenomenologicheskie variatsii na temu yazykovogo universalizma i relyativnosti // Vox/Golos. Vypusk 12 (iyun' 2012). (http://vox-journal.org/content/Vox12-Gogotishvili.pdf).

8. Grekhem Loren R., Kantor Zhan-Mishel'. Imena beskonechnosti. Pravdivaya istoriya o religioznom mistitsizme i matematicheskom tvorchestve. SPb.: Izd-vo Evropeiskogo universiteta v Sankt-Peterburge, 2011.

9. Ivanov Vyach. Gete na rubezhe dvukh stoletii // Ivanov Vyach. Sobr. soch. T. 4. Bryussel', 1974.

10. Ivanov Vyach. Dve stikhii v sovremennom simvolizme // Ivanov Vyach. Sobr. soch. T. 2. Bryussel', 1974.

11. Lermontov M.Yu. Chasha zhizni. 1831. Podrazhanie Baironu. (http://feb-web.ru/feb/lermont/texts/lerm06/vol01/le1206-.htm).

12. Losev A.F. Absolyutnaya Dialektika - Absolyutnaya Mifologiya. (http://philosophy.ru/library/losef/abs.html).

13. Losev A.F. Dialektika mifa. (http://philosophy.ru/library/losef/dial_myth.html).

14. Losev A.F. Problema simvola i realisticheskoe iskusstvo. M. 1976. (http://www.gumer.info/bibliotek_Buks/Culture/Los_ PrSimv/02.php).

15. Losev A.F. Filosofiya imeni. (http://www.gumer.info/bogoslov_Buks/Philos/fil_im/).

16. Lotman Yu.M. Kul'tura i vzryv. M.: Gnozis, 1992.

17. Nikolaev N.I. Predislovie // Pumpyanskii L.V. O poezii V. Ivanova: motiv garantii. (http://www.v-ivanov.it/wp-content/ uploads/2011/03/pumpyansky_o_poezii_ivanova_1925_2000_text.pdf).

18. Serio Patrik. Struktura i tselostnost': Ob intellektual'nykh istokakh strukturalizma v tsentral'noi i vostochnoi Evrope. 1920-30-e gg. / Avtorizovannyi perevod s frants. N.S. Avtonomovoi. M.: Yazyki slavyanskoi kul'tury, 2001.

19. Yampol'skii M. Skvoz' tuskloe steklo. M.: Novoe literaturnoe obozrenie, 2010. 